\title{
Hallazgo de bacterias comensales de la cavidad oral en tártaro dental de restos óseos de indigenas chonos
}

\section{Alfredo Linossier, Eugenio Aspillaga y Marta Gajardo}

\section{INTRODUCCIÓN}

Son múltiples las formas en que la Antropología Física puede contribuir al conocimiento de las características de las poblaciones humanas extintas. siendo las más fructíferas aquellas que permiten obtener información conducente a reconstruir los estilos de vida de esas poblaciones. La evaluación de las patologías, tanto a nivel individual como epidemiologico, así como de las alteraciones de la anatomía normal producto de actividades físicas particulares, y de otros aspectos de la biología de los individuos que componían las mencionadas poblaciones, permite contribuir a la reconstrucción de dichos estilos de vida como también a detectar actividades especializadas de algunos individuos.

Uno de los aspectos de interés a conocer de las poblaciones del pasado, y que constituye una información vital sobre los modos de vida de éstas, es la dieta que tenían. Usualmente este problema. - abordado desde la Antropología Física-, es estudiado evaluandc élementos como: la patología dentaria, enfermedad periodontal, patrones de abrasión y desgaste dentario. Menos, frecuentemente se introduce un análisis del contenido de elementos traza en los huesos, como indicadores de dieta.

El propósito general del presente trabajo es presentar los primeros resultados del análisis del contenido del flora bacteriana bucal-residual, conservada en el tártaro (sarro) dental, recuperado de cabezas óseas humanas correspondientes a una población extinta, con el fin de contribuir con otra estrategia que permita abordar aspectos en la reconstrucción de la dieta de poblaciones prehistóricas. Desde otra perspectiva, el estudio de: dieta del pasado, patologías dentarias y periodontales, en relación a la flora bacteriana asociada, puede con- 
tribuir al conocimiento de la dinámica evolutiva de las patologías de la cavidad oral a través del tiempo.

Los objetivos específicos son dar a conocer el primer hallazgo de bacterias propias del sarro dental en muestras de éste, obtenidas de cráneos de indígenas chonos, así como el discutir su posible utilidad para el estudio de las poblaciones humanas extintas.

El presente trabajo se ha efectuado en forma interdisciplinaria, entre un equipo de investigadores, formado por odontólogos especialistas en microbiología oral y un Antropólogo Físico de la Universidad de Chile.

\section{MATER1Al y MÉTODO}

El material empleado corresponde a residuos de sarro dental (tártaro), removido mediante instrumentación mecánica odontológica, obtenidos en cráneos, correspondientes a una muestra atribuible al grupo indígena conocido etnohistóricamente como "chonos". Los cráneos fueron recopilados en el marco del proyecto del mismo nombre (D.T.I. S-2653-8825) por E. Aspillaga y C. Ocampo en 1985 y por Ocampo en 1987 y poseen asociado un fechado radiocarbónico de $410+/-70 \mathrm{AP}$. Estos materiales se encuentran actualmente depositados en el Departamento de Antropología de la Universidad de Chile.

El tártaro fue macerado en mortero de porcelana para, posteriormente, realizar una suspensión en suero fisiológico, con lo que se realizaron los frotis que fueron tratados con tinción de Gram y montados en placas. Las placas fueron observadas en microscopía de luz bajo inmersión.

Para verificar la presencia de flora bacteriana contaminante, tanto del medio en que se encontraron los restos óseos como del laboratorio, se realizaron cultivos en medios enriquecidos de agar-sangre como controles, pudiénd ose determinar que las bacterias contaminantes eran escasas y en apariencia fueron las únicas que proliferaban en dichos medios, no comportandose así las que se encontraban presentes en el estroma del tártaro, calcificadas.

La condición de tártaro de los residuos se comprobó realizando la reacción de Von Kossas (ENNEver), para reconocer calcio. También se observaron las características del estroma, en comparación con muestras de tártaro extraído de individuos actuales.

Como control para las observaciones al microscopio de las bacterias, se compararon placas preparadas de la misma forma que las de la muestra estudiada, pero con tártaro proveniente de la cavidad oral de sujetos vivos. 


\section{Resultados}

La totalidad de las placas preparadas con sarro remanente de los restos estudiados (6) mostraban bacterias, principalmente formas cocáceas y bacilos Gram positivo, incluidas, en forma calcificada en el estroma del tártaro. Se observaron de tres a seis bacterias por grano (de distintos tamaños, dependiendo del preparado) observándose usualmente entre cuatro y treinta granos por campo (ver fotografía).

Los bacilos esporulados contaminantes del suelo y hongos que aparecen en las placas, están por fuera de los granos. Estas proliferaron en los medios de cultivo de agar-sangre, a diferencia de las formas bacterianas observadas en el estroma del tártaro.

Como contaminante ambiental se encontró a Bacillus subtilis, contaminante usual de los medios en los laboratorios.

Las bacterias observadas en el estroma del tártaro de origen arqueológico, son de características análogas a las observadas en preparaciones de tártaro fresco, no encontrándose diferencias al microscopio entre éstas y los fósiles en cuanto a su aspecto en el estroma.

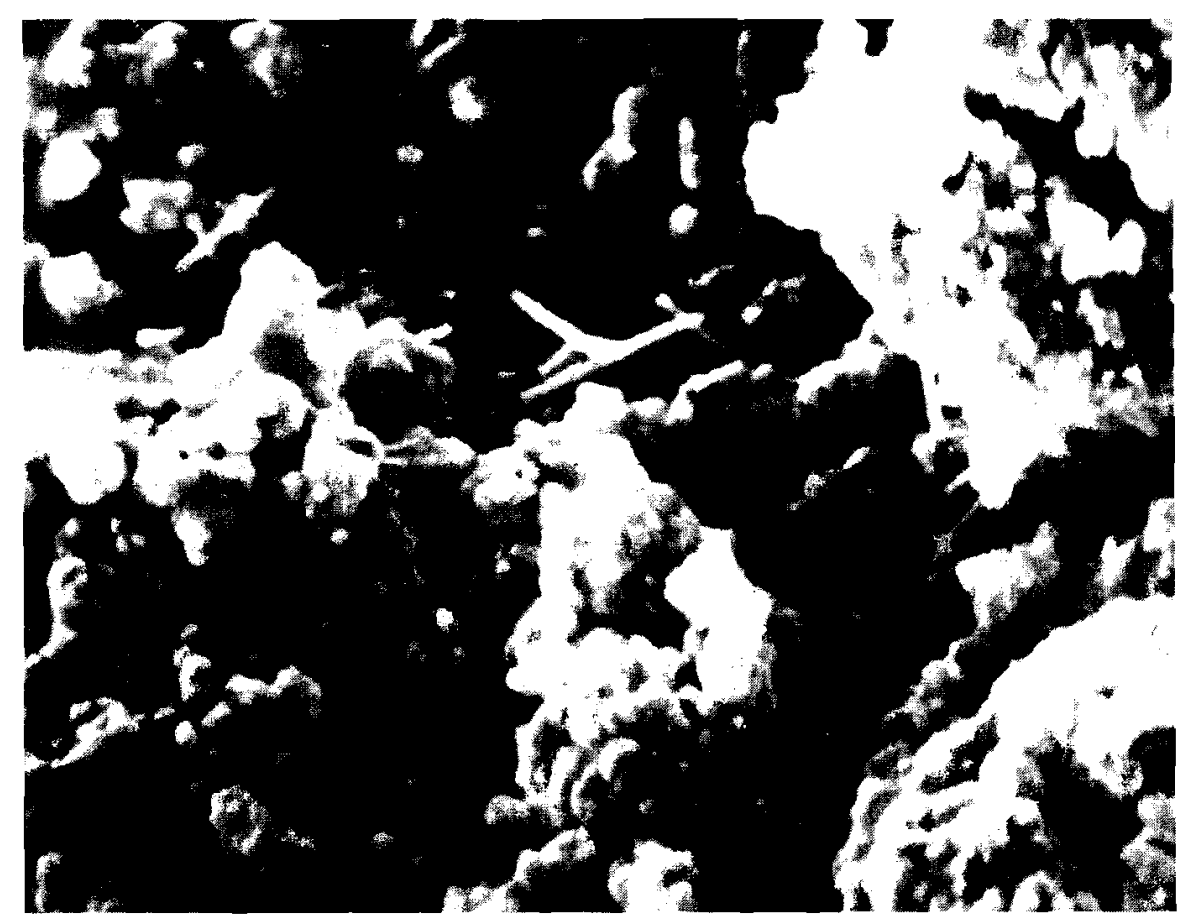

Microscopia de Barrido (4.000 x), Bacterias calcificadas. Juan Carlos Olavarr ía (IDIEM). 


\section{Discusión}

Como se insinúa en los resultados, existe una diferencia notable entre las bacterias propias del tártaro dental, en las muestras prehistóricas y otros microorganismos que pudieran actuar como contaminantes, -invalidando asi las observaciones-. Afortunadamente nuestro hallazgo permite diferenciar bien, en esta etapa temprana de la investigación, a ambos tipos de elementos asociados a los cálculos (tártaro). Es para nosotros claro que las bacterias, ya sean las formas cocáceas o los bacilos Gram positivos, que se encuentran incluidas en el estroma del sarro, corresponden a flora comensal de la boca que ha persistido en forma "fosilizada", al calcificarse. Por otra parte, estas bacterias no proliferan en los medios enriquecidos como lo hacen los microorganismos contaminantes.

Las bacterias conservadas en el tártaro del grupo humano estudiado se muestran, morfoscópicamente, muy semejantes o iguales a las presentes en los controles realizados con sarro actual. En el caso de las bacterias fósiles, en las que se conserva sólo la pared celular, no es posible en esta estapa de la investigación poder determinar especies. A futuro esperamos contar con los recursos y obtener resultados, al aplicar inmunofluorescencia monoespecífica para la determinación de especies.

Otras características de análisis y diferentes aspectos técnicos en relación a estos hallazgos se realizarán en un artículo con una orientación diferente al presente, en una revista especializada en odontología.

La importancia de poder estudiar los microorganismos comensales de la cavidad bucal, conservados en el estroma del tártaro, reside en dos aspectos importantes. El primero guarda relación con el hecho bien establecido de que la enfermedad periodontal, - tan común en las poblaciones prehistóricas-, se relaciona estrechamente con la formación de cálculos y la placa bacteriana dental (Mislowsky, CANis et al.). También otros autores describen una asociación con las caries (CAmpillo ). Siend o la mencionada flora comensal un elemento central en la formación del tártaro, su estudio puede mejorar la comprensión del origen y comportamiento de una patología tan difundida como lo es la enfermedad periodontal, no sólo en las poblaciones extintas, desde un enfoque paleopatológico, sino que también en actuales poblaciones, como la nuestra que posee una alta incidencia de enfermedad periodontal. Se abren así las puertas para un estudio, en una perspectiva evolutiva, de la relación parásito-huésped, lo que resulta de importancia para la comprensión del desarrollo de ciertas patologías.

El segundo aspecto, estrechamente ligado al anterior, guarda relación con el hecho, ampliamente aceptado en odontología, de que la flora comensal de la cavidad oral guarda estrecha relación, en cuanto a su estructura y composición, con los hábitos alimentarios de los individuos. Es por esto, que al poder analizarse las bacterias respon- 
sables de la formación de cálculos, se puede abrir una vía que permitirá sumando a los estudios de patología y desgaste dentario, conocer en forma más precisa los componentes de la dieta en las distintas poblaciones humanas extintas, lo que resulta de gran importancia para el arqueólogo en su intento de reconstruir los modos de vida de distintos grupos prehistóricos.

Por lo anterior se hace necesario que nuestros estudios avancen unos pasos más adelante, de modo de poder reconocer las diferentes especies de bacterias involucradas en la formación de tártaro y determinar la frecuencia de cada especie para cada muestra, y aunque no todos los organismos responsables de la generación del tártaro estén presentes, calcificados, los remanentes son por sí solos importantes para nuestras pretensiones. Sin embargo, hemos dado ya un gran paso al mostrar que es posible que se conserven bacterias ancestrales relacionadas con la formación de sarro dentario y que su estudio puede abrir grandes perspectivas, no sólo desde una "paleo microbiología bucal", que contribuya a conocer el comportamiento de las enfermedades de la cavidad oral, - a través del tiempo-; sino que también para la Antropología Fisica y la Arqueología, al poder relacionar dicha flora con otros aspectos de la biología de los individuos, en el caso de la primera, así como para contribuir a las reconstrucciones de los modos de vida, de interés para ambas disciplinas antropológicas.

\section{Conclusiones}

Nuestros resultados permiten afirmar que es posible obtener muestras de las bacterias asociadas al tártaro dentario, conservadas en la matriz de los cálculos adheridos a dientes de individuos de poblaciones humanas extintas.

Dado que la flora bacteriana asociada a la formación de sarro, se correlaciona en cierta medida con la dieta de los individuos, es que e] conocimiento de esta flora en poblaciones prehistóricas, puede contribuir al conocimiento de los habitos alimentarios de dichas poblaciones, especialmente si esta información se suma a otros estudios propendientes a lo mismo, como lo son el análisis de los patrones de abrasión, desgaste y atrición dentaria.

Como un aspecto importante de la biología de los grupos extintos, queremos destacar el hecho que, de poderse jdentificar las especies de bacterias presentes en el tártaro de las poblaciones extintas, la paleoantropología dispondrá de una poderosa herramienta para contribuir a conocer los desplazamientos de ellas y los contactos interpoblacionales resultantes, caracterizados por la distribución de elementos bacterianos típicos de cada grupo. 


\section{Bibliografía}

Campillo, Domingo. La enfermedad en la Prehistoria, Introducción a la Paleopatologia, Barcelona. Editorial Salvat, 1983, p. 74.

Canis, Marilin et al.: "Calculus Attachment", Journal of Periodontology. American Academy of Periodontology, [Chicago, Illinois], vol. 5, $\mathrm{N}^{\circ} 80,1979$, pp. 406-415.

Ennever, J. "Intracellular Calcification by Oral Filamentous Microorganisms". The Journal of Periodontology, American Academy of Periodontology, [Chicago, Illinois] 1960, pp. 304-307.

Mislowsky, William; Mazzella, Walter. "Supragingival and Subgingival Plaque and Calculus Formation in Humans" Journal of Periodontology, [Chicago, Illinois], 1974, pp. 822-829.

Ocampo, Carlos y Aspillaga, Eugenio: "Breves notas sobre una Prospección Arqueológica en los archipiélagos de las guaitecas y de los chonos", Revista Chilena de Antropologia, [Santiago] N 4, 1984, pp. 155-156. 